\title{
TTR
}

Traduction, terminologie, re?daction

\section{Translation as Writing Across Languages: Samuel Beckett and Fakir Mohan Senapati}

\section{Paul St-Pierre}

Volume 9, numéro 1, 1er semestre 1996

Le festin de Babel

Babel's Feast

URI : https://id.erudit.org/iderudit/037246ar

DOI : https://doi.org/10.7202/037246ar

Aller au sommaire du numéro

\section{Éditeur(s)}

Association canadienne de traductologie

ISSN

0835-8443 (imprimé)

1708-2188 (numérique)

Découvrir la revue

Citer cet article

St-Pierre, P. (1996). Translation as Writing Across Languages: Samuel Beckett and Fakir Mohan Senapati. TTR, 9(1), 233-257. https://doi.org/10.7202/037246ar
Résumé de l'article

Translation as Writing Across Languages: Samuel Beckett and Fakir Mohan Senapati - En prenant pour exemples les traductions par Samuel Beckett de ses propres textes et cinq traductions d'un passage d'un roman indien de la fin du dix-neuvième siècle, cet article veut démontrer que l'on ne peut séparer d'une manière absolue la traduction de l'écriture, que l'originalité et la créativité ne sont pas les attributs de cette dernière seulement, que la traduction ne se réduit pas à une simple reproduction. Dans le cas de Beckett, la traduction a pour fonction de lui permettre de commencer et de continuer à écrire; c'est un moyen pour lui d'explorer un des grands thèmes de son oeuvre, la relation entre l'écriture et la ou les langues. Dans celui des cinq traductions du passage du roman en oriya de Fakir Mohan Senapati, Chha Mana Atha Guntha, les différences entre les versions sont examinées afin de faire voir jusqu'à quel point la traduction est toujours un acte de création.
Tous droits réservés (C) TTR: traduction, terminologie, rédaction — Les auteurs, 1996 ce document est protégé par la loi sur le droit d'auteur. L'utilisation des services d'Érudit (y compris la reproduction) est assujettie à sa politique d'utilisation que vous pouvez consulter en ligne.

https://apropos.erudit.org/fr/usagers/politique-dutilisation/ 


\section{Translation as Writing Across Languages : Samuel Beckett and Fakir Mohan Senapati ${ }^{1}$}

\section{Paul St-Pierre}

What I will attempt to show in this paper is that translation cannot be divorced from writing, that originality and creativity are not characteristic only of the latter, that translation is not mere reproduction. My thesis here is that translation is a part of the creative process. This will be developed in relation to Samuel Beckett's translations of his own works and a number of translations of a nineteenth-century Indian novel. In the case of Samuel Beckett, translation was a way both to begin and to continue the writing process, a way for him to explore the relation of writing to language. Translation provides Beckett with the possibility of writing across languages. But I do not wish to limit my remarks to what may be considered a special case: an author translating his own works. Thus I will also briefly discuss five translations into English of a passage from an Oriya ${ }^{2}$ novel by Fakir Mohan Senapati, Chha Mana Atha Guntha. The existence of these translations and the differences between them will be examined for the purpose of

1. I would like to express my gratitude to the Social Sciences and Humanities Research Council of Canada for funding which made possible the research carried out on Fakir Mohan Senapati.

2. Oriya is one of the eighteen official languages of India. 
understanding the extent to which the practice of translation is always an act of creative writing.

\section{I - Samuel Beckett}

\section{A. Writing and Translation}

Among the first works published by Samuel Beckett were three translations ${ }^{3}$, from Italian into English, which appeared in This Quarter in 1930. Over the years these translations were followed by numerous others, mostly but not exclusively of literary texts (poems, short stories, plays and art criticism). With one exception Beckett's collaboration on the translation into French of Joyce's "Anna Livia Plurabelle" - the translations are all into English, and the source languages include Spanish and Italian, in addition to French.

It is in terms of his own work, however, that Beckett's activity as a translator is particularly significant, and his role varies from supervising the work of others to translating entire works himself. Languages here too multiply, but with a difference: his translations are into, and not from, several languages, for, in addition to translating into English and French, Beckett participated in the translation of his works into German and Italian ${ }^{4}$. This difference, going against conventionally-held wisdom that one should translate only into one's mother-tongue, seems to a certain extent to depend upon Beckett's double status as both author and translator, a status which - at least in the minds of his readers - affords him greater

3. "Delta" by E. Montale, "Landscape" by R. Franchi, and "The Homecoming" by G. Comisso.

4. For examples of Beckett's role in the translation, or retranslation, of his work into German and Italian, see his annotated copy of Endspiel (Beckett collection, Washington University) and his comments on the Italian version of Still (Beckett collection, Reading University). 
leeway in terms of the original text. The changes Beckett makes in the process of translation are considered not only acceptable but significant, an indication of the reading of the text adopted by the author himself. The unquestioning acceptance of these changes, by readers and critics alike, would seem to indicate that, at least in the case of an author translating his or her own works, the standard although by no means unproblematic - measure of the faithfulness of a translation is no longer operative: the conformity, or lack thereof, of the translation to the form or to the sense of the original text is no longer pertinent, replaced by the author's mere presence, which becomes, for such readers and critics, the guarantee that what is essential in the work has not been lost in the passage from one language to another. Indeed, according to this point of view, what has been lost can only be what is merely accessory, and the gain in self-translation is precisely that the work is reduced by the author-transiator to its essential elements. Such then is what guides the attitudes of many readers towards a translation by an author of his or her own work, and although this position may not be totally false (a translation is indeed a particular reading by the author) it is fundamentally unsatisfactory, since its effect is to reduce the text to the intended meaning of the author.

A somewhat more interesting function can be given the author's double presence, however, if the process of self-translation is considered to be one of pluralization rather than of reduction, if translation is considered in this case to be a continuation of the writing process. To pose the problem being raised here in other terms and within the framework of a particular text: can Malone Dies be considered a translation of Malone meurt despite the numerous passages deleted and added, to mention only the most obvious changes, or would it not be more exact to see Malone meurt as a draft, if not first then also not final, of Malone Dies? From such a perspective one version cannot be reduced to another, nor can any clear and definite origin or finality be assigned, thereby underlining the basic instability which inhabits Beckett's universe, a universe characterized, as are signifying practices in general - to use Julia Kristeva's term, by "transposition," that is, the "passage d'un système de signes à un autre." (J. Kristeva, 1974, p. 59) It is 
this "passage" which I will now attempt to describe, through an analysis of a sampling of the changes Malone meurt undergoes in its translation from French into English.

\section{B. Transitions}

In the very first sentence of Malone Dies the narrator announces his imminent demise: "I shall soon be quite dead at last in spite of all." $(1979, \text { p. } 165)^{5}$ This 'very first' sentence announcing the imminent death of the narrator is, however, itself already the result of another death, that of memory and of orality, and insofar as it is the culmination of a previous process it is not 'first':

this must be going on now for over a week, it must be over a week since I said, I shall soon be quite dead at last, etc. Wrong again. That is not what I said, I could swear to it, that is what I wrote. [...] Yes, I shall soon be, etc., that is what I wrote when I realized I did not know what I had said, at the beginning of my say, and subsequently [...]. (p. 192)

This 'first' sentence is in fact the result of an attempt on the part of the narrator-writer not to forget. And while he waits for the end to come, between the first and last sentences of the novel, there are fictions: "I shall tell myself stories [...] not [...] the same kind of stories as hitherto." (p. 165) Malone meurt/Malone Dies thus presents a triple passage - from life to death, from spoken to written language, from one type of fiction to another - , all of which - life, language, and fiction - will end with Malone.

In this triple passage, the narrator's position is essentially that of an intermediary, a go-between, or, in the etymological sense of the word, of an interpreter ${ }^{6}$ (that is, a translator), an intermediary

5. Editions referred to: Malone meurt (1971); Malone Dies, in The Beckett Trilogy, "Picador" (1979).

6. Cf. W.W. Skeat (1921), p. 305. 
position between life and death, partaking of both and defined by neither: "I am being given, if I may venture the expression, birth to into death, such is my impression." (p. 260) And just as the narrator is situated at some impossible point between life and death, being born and dying at one and the same time, he will himself disappear: "I shall not weigh upon the balance any more, one way or the other. I shall be neutral and inert." (p. 165) Nor will the stories he will tell be any different: "[...] there will be no ugliness or beauty or fever in them any more, they will be almost lifeless, like the teller." (p. 165) There is thus no clear distinction between the stories and the storyteller, in terms both of Malone and his creatures ("I write about myself with the same pencil and in the same exercise-book as about him. It is because it is no longer I [...]," p. 191), as well as of Beckett and his creature Malone (Malone writes (p. 216): "Yes, that's what I like about me, at least one of the things, that I can say, Up the Republic!" thereby recalling, but not exactly repeating, Beckett's contribution to Authors Take Sides on the Spanish War ${ }^{7}$ ) The fictionalization of the narrator-writer (Malone, Beckett) - the counterpart of this confusion between characters and creator represents the dissolution which takes place through the writing process, and which affects not only the subject but also the object, the relation between the writing subject and that which is being written about: "[...] my notes have a curious tendency, as I realize at last, to annihilate all they purport to record." (p. 238) A further confusion which takes place is that of the separation between the functions of writer and translator, since the translation here problematizes the writing process rather than underscoring its unique character and originality.

\section{From Malone meurt to Malone Dies}

Now let us turn to the particular changes Malone meurt/Malone Dies undergoes in the passage from French into English, notably the

7. Beckett's contribution was: "iUPTHEREPUBLIC!" See Authors Take Sides on the Spanish War (London, Left Review, 1937), p. 6. 
deletions (over 1000 words, including some forty-five sentences) and the additions (approximately 300 words).

\section{i) Position and Distance}

The passages most commonly deleted contain the narrator's comments on what he has just said and serve to create an ironic distance separating the narrator, his discourse, and the reader, who is led to understand that nothing - neither the affirmation nor the denial - can be accepted as 'truth' about a pre-existing external world ${ }^{8}$. Such comments open up within the text a space, which is that of the creation of fiction:

Je soufflerai volontiers dessus mais 1 should like to breathe on elle est trop loin. Ce n'est pas vrai. Peu importe, mon souffle ne 182)

la ternirait pas. (p. 39)

[...] afin qu'ils puissent savoir $\quad[\ldots]$ in order that they may très précisément ce que c'est qui know very precisely what ose empêcher leur bonheur exactly it is that dares prevent d'être sans mélange. Car c'est là their happiness from being une chose qu'on suppporte unalloyed. (p. 223)

difficilement d'ignorer. (p. 114)

Mais depuis j'ai dû tout oublier. But since then I must have Non, pas tout, il est rare qu'on forgotten it all. (p. 227) oublie tout. (pp. 121-122)

Similar comments on the text are also added in the English version:

8. Deletions from the French original and additions in the English translation are in italics in the passages cited. 
Et quand il se remettait en branle, après une halte, il faisait penser à un gros duvet que le souffle arrache de l'endroit où il s'était posé. (p. 36)
And when, after a halt, he started off again, it was like a big thistledown plucked by the wind from the place where it has settled. There is a choice of images. (p. 180)

The still nights too, still as the grave as the saying is, were nights of storm for me, clamorous with countless pantings. (p. 189)

Taken together the deletions and additions emphasize the ambiguity of the relations of the narrator-writer to his text: the comments create a point of reference, and of judgement, both within the narration and seemingly exterior to it, with the constant passage from within to without. At the same time as this position is established it is also put into doubt, thereby reflecting Malone's own fluctuating relationship to the stories he tells and through which he tells/creates himself. For at the same time as the comments give a certain presence and existence to Malone, separate from his narration, they also - through their tenor as well as their very existence-draw attention to the narration as fiction, and in this way accentuate Malone's status as a creation of the very tale he is telling. Other deletions also underline the importance of the narrator's position, no longer as a writing-subject, as in the previously cited examples, but as an object of perception:

On va pouvoir m'enterrer, on ne me verra plus à la surface. D'ici là je vais me raconter des histoires, si je peux. (p. 8)

Alors je jouerai tout seul, je ferai comme si je me voyais. (p. 10)
While waiting I shall tell myself stories, if I can. (p. 165)

Then I shall play with myself. (p. 166) 
[...] et où il y avait soleil et abri pour qui en avait vraiment besoin. Mais il s'agit bien de moi! (p. 86)
[...] and a little sunshine and shelter for those who direly needed them. (p. 208)

ii) Verisimilitude and Writing

A second category of deletions contains details which serve to locate the fiction in relation to reality, through what Roland Barthes (1968) termed "l'effet de réel":

Il était réputé bon saigneur et dépeceur de porcs et était très demande, assez demandé, comme tel, car il prenait moins cher que le boucher et même souvent se contentait, pour toute rémunération, d'un jambonneau ou d'un peu de fromage de tête. Que tout cela est vraisemblable. Car il aimait ce travail et était fier de savoir si bien le faire, en artiste, selon le secret que son père lui avait transmis et dont il se considérait le dernier dépositaire. (p. 42)
He was highly thought of as a bleeder and disjointer of pigs and greatly sought after, I exaggerate, in that capacity. For his fee was lower than the butcher's, and he had even been known to demand no more, in return for his services, than a lump of gammon or a pig's cheek. How plausible all that is. (p. 183)

The details omitted from the translation gave the description greater verisimilitude in French, underlining the psychological motivation of the character and contradicting the comment by the narrator that his tale is merely plausible and not true. Other deletions relate to adverbial elements, their elimination providing the reader with less information concerning the manner, place, time, etc:, events occurred. Certain of the additions to the English text also add realistic details but their most usual function is to establish parallel structures, either through the exact repetition of certain words or expressions or through the use of synonyms and antonyms: 


\section{Realism:}

Lemuel se rendit aux cuisines avec deux seaux emboîtés l'un dans l'autre. (p. 178)

Repetition:

Carrying in one hand two buckets wedged one within the other Lemuel proceeded to the vast kitchen, full of stir and bustle at that hour. (pp. 257-258)
L'essentiel est de s'alimenter et d'éliminer, si l'on veut tenir. Vase, gamelle, voilà les pôles. (p. 17)

En avant, en arrière, que ça doit être bon. (p. 106)
What matters is to eat and excrete. Dish and pot, dish and pot, there are the poles. (p. 170)

Back and forth, back and forth, that must be wonderful. (p. 219)

\section{Synonyms and antonyms:}

Et qu'y a-t-il de changé pour que je m'excite de cette façon? (p. 84)

Et comme si cela ne suffisait pas pour m'assurer qu'il s'agit vraiment du dehors [...] (p. 105)

[...] un coup si violent qu'il tomba a la renverse. (p. 155)
But why this sudden heat, has anything happened, anything changed? (p. 207)

\section{And as if that were not} enough to satisfy me it is the outer world, the other world [...] (p. 218)

[...] so violent a blow that he fell down backwards, or perhaps I should say forwards. (p. 245)

The repetition of words and expressions and the use of synonyms and antonyms, in addition to producing a semantic effect - most usually one of foregrounding - , result in the accent being placed on the very structure and thythm of the sentence, on the particular linguistic set of signs being used by 
the narrator. Deletions also affect such parallel structures, already present in the French text:

Et je sens même une étrange envie me gagner, celle de savoir ce que je fais, et pourquoi, et de le dire. (p. 32)

Et si de prime abord ils n'étaient pas d'accord sur ce qu'ils avaient vu et sur sa signification ... (pp. 51-52)
And I even feel a strange desire come over me, the desire to know what I am doing, and why. (p. 178)

And it at first they were not in agreement about what they had seen, [...] (p. 188)

\section{iii) Languages}

The translation by Beckett of his own texts not only undermines the distinction between original text and translation, and thus also that between writing and translation; it also raises the question of the language, or languages, of the texts. Two - English and French $\sim$ are present, within each version separately, as well as within this composite work Malone meurt/Malone Dies constituted by the two versions of the text taken together. Thus Malone writes:

Oui, c'est ce que j'aime en moi, Yes, that's what I like about enfin une des choses que $j$ 'aime, me, at least one of the le don de pouvoir dire Up the Republic! par exemple, ou Chérie! (p. 102) things, that I can say, Up the Republic! for example, or, Sweetheart! (p. 216)

Writing in French, Malone presents himself as speaking two languages - English (Up the Republic!) and French (Chérie!), one of which - French - is not his own: "Elle les écartait de ses flancs, je dirais brandissais si j'ignorais encore mieux le génie de votre langue." (p. 46) This sentence, omitted from Malone Dies, underlines the foreignness of French ("votre langue") for the narrator. In the English version, there is no indication that Malone speaks French. But this change to English, reducing Malone to one language alone, brings with it elsewhere in the text the mark of the 
other language, French: "Jackson called me the merino, I don't know why, perhaps because of the French expression." (p. 200) An expression linked to a particular idiom - here French ("Laisser pisser le mérinos") - bears with it, once transposed into English, the mark of that idiom. Similarly the change in language causes certain modifications in the text to be made, modifications which point both to the language of the original text and that of the translation:

\begin{tabular}{|c|c|}
\hline $\begin{array}{l}\text { Une femme dit cependant: Ils } \\
\text { t'emmènent en bateau, ce qui } \\
\text { déclencha une tempête de rires } \\
\text { si forte que des couples se } \\
\text { formèrent spontanément, } \\
\text { s'étreignant, chancelant, et } \\
\text { chacun riant par-dessus l'épaule } \\
\text { de son partenaire. (p. } 177 \text { ) }\end{array}$ & $\begin{array}{l}\text { One woman however } \\
\text { did pass a witty } \\
\text { remark, to good effect. } \\
\text { (p. } 257 \text { ) }\end{array}$ \\
\hline $\begin{array}{l}\text { On l'appelait l'Anglais, } \\
\text { quoiqu'il fut loin de l'être, } \\
\text { peut-être parce qu'il s'exprimait } \\
\text { en anglais de temps en temps. } \\
\text { (p. 180) }\end{array}$ & $\begin{array}{l}\text { He was called the Saxon, } \\
\text { though he was far from } \\
\text { being any such thing. (p. } \\
\text { 258) }\end{array}$ \\
\hline
\end{tabular}

In the first example, the pun ("emmener quelqu'un en bateau") and the reactions to it are voided of substance in the English version, this substance being intrinsically connected to the signifiers of the French language. In the second example, the change to English brings about a transposition from the otherness of an Englishman in a French context to that of a Saxon in an English one.

In addition to the traces of the two languages in each version, the passage from Malone meurt to Malone Dies is one which the term 'translation' does not adequately describe, implying as it does an equivalent text in each language. As has already been seen, Beckett's self-translation continues the writing process. One further example of this is the following: 
Un jour Sapo arriva chez les Louis plus tard que d'habitude. Mais sait-on à quelle heure il avait l'habitude d'y arriver? (p.

62)
The Lamberts. One day Sapo artived at the farm earlier than usual. But do we know what time he usually arrived? (p. 194)

At least two differences can be noted here: firstly, that of the change of name - from Louis to Lambert - less interesting perhaps for the particular literary reference ${ }^{9}$ than for the necessity for both versions to be read together for the reference even to exist; secondly, the change between "plus tard que d'habitude" and "earlier than usual," a change which in a sense confirms the implication, contained in the second sentence, that Sapo's usual time of arrival is not known. Neither version can be considered definitive, however; what is important is at one and the same time their contradiction and coexistence, made possible by that combination of writing and translation that Beckett's self-translation is.

A brief examination of the excerpts of Malone meurt and Malone Dies published prior to their definitive versions confirms this interconnection of writing and translation. Part of Malone Dies was published in Transition fifty (1950). Designated a translation, this English excerpt is significantly different from the final versions of Malone meurt and Malone Dies and, as a translation, it points to an earlier unpublished French text, also differing from the final versions. Thus, at least insofar as the published passage is concerned, there exist four separate versions, and the final French text - the "original" text - is in fact the product of an ongoing writing process, beginning in French (the unpublished French text corresponding to the English excerpt in Transition fifty) continuing on in English (the excerpt published in Transition fify) and then again in French (Malone meurt) before translation once more into English (Malone Dies). That such a process does in fact take place would seem to be confirmed by a passage from Malone meurt

9. The reference is to the novel by Honore de Balzac, Louis Lambert. 
published in Les Temps modernes under the title "Quel malheur..." (S. Beckett, 1951). To the comment contained in the excerpted passage - "mais cela lui passera" (p. 395) - the final French version of the novel adds "ce qui est humain," so that the comment then reads in Malone meurt, "ce qui est humain, mais cela lui passera." (p. 96) In Malone Dies, only the first part of the comment, added in Malone meurt, is translated: "which is only human." (p. 213) The changes made between these three versions point to an ongoing writing process which cannot be reduced to the differences between the languages involved; they reflect rather the indissolubility of the links in Beckett's works between writing and translation.

\section{II - Fakir Mohan Senapati}

After having discussed the case of an author translating his own work, I would now like to turn to a more usual case of translation. Through the discussion of a short passage in five different translations of a late nineteenth-century novel I hope to show that translators intervene constantly on all levels of the text, that translation must of necessity be considered a form of writing. Indeed, the difference between self-translation and the translation of a work by another is not one of kind; rather the difficulties involved are in both cases much the same (most notably, codes, contexts and cultures which do not precisely overlap); what differs, however, is the reception given the changes made by authors translating their own works and those by translators other than the author.

\section{A. Five Translations}

First a brief word about the five translations of the first few sentences of Chapter 22 of Chha Mana Atha Guntha (literally: "Six Acres and Thirty-Two Decimals"), the first social realist novel in an Indian language, in this case Oriya. The novel, by Fakir Mohan Senapati, was published in serialized form in 1897 and appeared as a volume in 1902 . This particular passage was chosen precisely 
because of the different translations of it which exist ${ }^{10}$. Translation 1, by K.M. Acharya, appeared in an anthology of selections from Indian writing published by the Sahitya Akademi, the official Indian cultural institution whose mission is to further exchanges between the most prominent Indian languages. Translation 2 is excerpted from a translation by R. S. Mishra and J. Nayak, presently under revision with a view to publication. Translation 3 was done by a non Oriya in consultation with a group of fifteen Oriya literary translators. Translation 4 was produced by C.V. Narasimha Das as part of a complete published translation of the novel. Translation 5 was published as part of a different complete translation of the novel, by Nuri Misra. Given the somewhat eccentric nature of the published complete versions (translations 4 and 5), they will be dealt with separately. The comparison of the different translations is of interest to us insofar as it underscores the degree to which translators intervene on all levels of the text. The translator is confronted with choices to be made, and the solutions to these choices are not determined exclusively by the original text itself, for otherwise the choices of the various translators would scarcely differ. It is the intervention of the translator between the reader and the original text which I wish to highlight here, an intervention which is essentially creative in nature, taking the original as its point of departure but determining the nature of the transformation to be effected, and the means of doing so, in terms of other criteria.

\section{B. Translations 1, 2, and 3}

There are two obvious errors in the translations of the passage: the name of the river in Translation 1, given as 'Nirupa' rather than 'Birupa', and the reference to 'the weekly market' in Translation 2, a misreading of the Oriya word for 'ghat'. The first is possibly simply a misprint; the second most likely a lapse in attention on the part of the translators.

10. See the Appendix for the passages from the five translations, and pertinent bibliographical information. 
Apart from these errors it is, however, the other variations between the passages which are of interest, in that they reflect different options selected by the translators in the realization of the Oriya original in English. These differences relate essentially to questions of sentence structure, verb tense, and cultural allusion.

\section{Table 1: Sentence Structure}

\begin{tabular}{|lcccc|}
\hline & Incomplete & Simple & Compound & Complex \\
Translation 1 & & 6 & & \\
Translation 2 & & 3 & & 2 \\
Translation 3 & 1 & & 2 & \\
& & & & \\
\hline
\end{tabular}

As Table 1 shows, there is a clear difference between the translations on the level of sentence structure, with regards both the number of sentences as well as their type. Whereas Translation 1 divides the passage into six simple sentences, introducing variety only through a verb-subject inversion in sentence 4, Translation 2 opts for a mixture of simple and complex sentences, five in all. Translation 3 has fewer sentences than the other two translations (a total of three), beginning the passage with a sentence which is structurally incomplete and following it with two compound sentences. The variation noted here has a certain significance in that it reflects the priority each translation gives either to the original text or to the target language. Translation 2, notably, varies English sentence structures, as does Translation 3; in this, they distinguish themselves from Translation 1. The way they do this, however, differs, and reflects the priority accordedEnglish-language structures in the case of Transiation 2, and the structures of the original text in Translation 3. 


\section{Table 2: Verb Tense}

\begin{tabular}{|ccccc|}
\hline & $\begin{array}{c}\text { Simple } \\
\text { Present }\end{array}$ & $\begin{array}{c}\text { Simple } \\
\text { Past }\end{array}$ & $\begin{array}{c}\text { Present } \\
\text { Perfect }\end{array}$ & $\begin{array}{c}\text { Past } \\
\text { Perfect }\end{array}$ \\
Translation 1 & 3 & 1 & 1 & 1 \\
Translation 2 & & 6 & & 1 \\
Translation 3 & 2 & 2 & 1 & \\
\hline
\end{tabular}

Using the simple present and the present perfect, Translation 1 locates the narration in the present. For past events the simple past and the past perfect are used. In Translation 2, the narration is in the past, and prior events are recounted using the past perfect. Translation 3 takes as its point of reference the present once again, and prior events are narrated using the simple past alone.

\section{Table 3: Cultural Allusion}

\begin{tabular}{|c|c|c|c|c|}
\hline Translation I & $\begin{array}{l}\text { the } \\
\text { catastrophic } \\
\text { floods }\end{array}$ & $\begin{array}{l}\text { eighth day } \\
\text { of Bhodua }\end{array}$ & $\begin{array}{l}\text { eighth } \\
\text { year }\end{array}$ & \\
\hline Translation 2 & a flood & & $\begin{array}{l}\text { eighth } \\
\text { year }\end{array}$ & $\begin{array}{l}\text { of the reign } \\
\text { of king } \\
\text { Mukund } \\
\text { Dev }\end{array}$ \\
\hline Translation 3 & $\begin{array}{l}\text { the great } \\
\text { floods }\end{array}$ & $\begin{array}{l}\text { eighth day } \\
\text { of } \\
\text { the month } \\
\text { of Bhodua }\end{array}$ & $\begin{array}{l}\text { eighth } \\
\text { year }\end{array}$ & $\begin{array}{l}\text { of the } \\
\text { dynasty of } \\
\text { the kings of } \\
\text { Puri }\end{array}$ \\
\hline
\end{tabular}

Various elements in the translated passage can be cited as examples of cultural allusions. These include the place names, which 
receive - once allowance is made for the translation errors already mentioned - approximately the same treatment in all three translations. Thus all the translations add to the name of the river (Birupa) a more or less precise indication as to what the name refers to ("on the bank of," "the bank of the river," "on the river"). None of the translations actualize another possibility, "on the Birupa," which would have been sufficient for native Oriyas since the river - an actual river in Orissa - forms an integral part of their experience of the world. On the other hand, none of the translations adds a further gloss to the name of Orissa's former capital and one of its most ancient cities, Cuttack, even though the importance of the city is unlikely to be recognized immediately by many readers of the English-language version of the text. Differences do exist, however, in the treatment of culturally specific terms in the sentence mentioning the floods which washed away the village of Gopalpur. These differences have to do with the qualification of the floods as well as with the indication as to when the floods took place. Thus Translation 1 indicates their seriousness ("catastrophic") and specifies when they took place ("eighth day of Bhodua in the eighth year"), without however qualifying "Bhodua" and merely italicizing "the eighth year," with no further explanation. The time frame of the event is thus at its most general. Translation 2 singularizes "flood" and further banalizes the event through the use of the indefinite article (one "flood" among many). The reference to the particular day on which the event occurred is omitted, but "the eighth year" is made more precise than in the first translation. The omission of the reference to the day has the effect of eliminating the repetition ("eighth day"/"eighth year"), further lessening the significance and ominous nature of the event. In Translation 3 the "floods" are given an importance which is at once subjective and objective through the use of the adjective "great" and of the definite article. Both the day and the year are specified and qualified; it is indicated that "Bhodua" refers to a division of the calendar and the nature of the reference 
to the year, through mention of the dynasty rather than the reign of a particular king, is made more general ${ }^{11}$.

What I wish to draw attention to through this rapid comparison is not that one or other of the translations is preferable, but that at every point in the translation process decisions have been made as to how to re-express the original work. Despite the linguistic and cultural constraints within which the translators are working, or rather because of them, these decisions have led to different results in the rewriting of the text in the new language. Indeed it is very precisely the existence of such constraints which engages translators in a process of writing; the hurdles which render translation difficult and at times impossible are also those which render it creative and original. Thus each translation is characterized by its own particular choices and style. Translation 1, for example, emphasizes the referential elements of the text and creates cohesion within the passage almost exclusively through such geographical mentions. Translation 2, on the other hand, makes use of redundancy as its main stylistic device. Thus "bank" and "river" are used together to qualify "Birupa," and people do not merely "cross" the river or "take the ferry," but rather "take the ferry to cross the river." As for Translation 3, its principal trait is the use of a variety of sentence structures and styles. The telegraphic style of the first sentence contrasts with the length and details of the compound sentence which follows it.

\section{Translations 4 and 5}

At this point it is of interest to turn to Translations 4 and 5 of the same passage. The first is taken from a complete translation of the novel published under the title The Stubble Under the Cloven Hoof. Termed by its publisher "an imaginative recast," between the extremes of a strict translation and an adaptation, it is, as this

11. Through the mention of Puri, one of the four holiest places in all of India for Hindus, whereas the names of the kings of Puri, Dev, would not necessarily be recognized by non Oriyas. 
particular passage would lead one to expect, a good deal longer than the original novel. The translator, in his preface, justifies the way in which he has written (the preface is entitled "The Author to the Reader") his translation, with comments such as: "I tried to put myself into the frame of mind in which Fakir Mohan must have written the Oriya novel"; "Fakir Mohan himself, I fancy, would have written something vitally like this book if he had come to write in English today"; "My book produces, both in thought and emotion, the same effect of gaiety, exuberance, buoyancy, and rollicking conviviality as Fakir Mohan's Oriya book." One can recognize here the arguments translators have used for ages to justify liberties taken with the form or meaning of original texts, arguments which have as their basis an identification with the author and with the authorial function. This is made explicit by Das:

A person who sets out to recast a vernacular harmony of this kind into Indo-Anglian accents should be a creator and not a mere copyist. Unless he is a creator himself, he is likely to be, in the final assessment, more a maker of an Oriya-to-English Dictionary than a refurbishing artist. It is not my ambition to produce a dictionary out of a work of art. My work is an imaginative and succulently larded English recast of an Indian classic, with windows of modern consciousness, and not merely a case-hardened and lumbering literal rigmarole.

This translation raises the question of the limits of translation, of the extent to which it is possible to distinguish in any absolute way between creative writing and translation. Das here translates and creates, as did Beckett, and as do in their own more timid ways the translators of versions 1,2 and 3 . The constraints of language and of culture become evident and are celebrated rather than denied, as translation and writing are no longer opposed.

The principal characteristic of Translation 4 is its addition of both information and commentary to the original text. What in the other translations merited merely passing reference (Cuttack and Birupa, for example) is here given central prominence. Thus the 
passage now begins with a description of Cuttack, which has become a central figure and not merely a destination for travellers. The river too is more fully described and elaborately qualified: "the slender Birupa," "meanders on the north and seems to guard the northern approaches to the city like a redoutable sentinel," "second aquatic line of defence," "the meandering stream." In keeping with the dialogic tone of the novel as a whole, the essentially neutral descriptive nature of this passage has been transformed through the use of a strong narrative voice, evident in the characterizations and comments. The identification of the translator with the author has led to a text which is at one and the same time a translation and a pastiche.

Translation 5, the other published version of the novel, takes the opposite tack from translation 4, reducing the passage to its barest bones. Just as the amplification in the previous translation was justified in terms of writing, so too are the reductions in this version. Translator Nuri Misra states his aims as follows in his brief "Preface": "A Plot of Land' has been rewritten from the original Oriya social novel 'Chha mana Atha Guntha' by Fakir Mohan Senapati. [...] Without changing the structure and style of the original story, the translator has tried to rewrite the same so as to enable it to be used as an easy reader for whom [sic] English is a second language." [Emphasis added] However, whereas the translator of The Stubble Under the Cloven Hoof identified with the writer, Misra has produced a text in function of a particular reader. The changes made - reduction of the vocabulary and structure of the novel to their simplest form - reflect this purpose.

The difference between the approaches taken by the translators of the two published versions raises the question of the image translators have of their potential readers and the effect such images play in the actual translations produced. This is of particular pertinence in the context of translation of writings in Indian languages into English, since the readership can be either national or international. The choice of one or other as the 'model reader' will affect not only which words and structures are chosen but also which will need to be explained, where notes or other critical 
intrusions on the part of the translator are necessary. The reader for whom the translation is being produced affects the form translations take, the way translations transform their originals.

\section{Conclusion}

I have presented here two somewhat exceptional cases of translation, with a view to showing that whatever differences may exist between them they both raise the question of the relation of translation to writing, putting into doubt both the purportedly reflective nature of the first and the originality often considered exclusive to the second. These case studies demonstrate two things: 1) that there do not exist any fundamental differences between translation and self-translation - both can be seen as processes of pluralization -, but rather that it is the way in which the changes which occur in the translation process are perceived and received that leads to their differentiation, and 2) that translation is a form of writing, or more exactly of rewriting, and the two practices cannot be distinguished in any systematic way. The blurring of the distinction between translation and writing makes it possible to return to translation the originality and the prestige it once had and which this distinction had deprived it of, the 'originality' of 'creative' writing relegating translation to a devalued paradigm of reflection, refraction, and reiteration.

\section{References}

BARTHES, Roland (1968). "L'Effet de réel," Communications, 11, pp. 84-89.

BECKETT, Samuel (1950). Excerpt of Malone Dies, in Transition fifty, VI, pp. 105-106.

(1951). "Quel malheur..." (Excerpt of Malone meurt),

Les Temps modernes, 71 (septembre), pp. 385-416.

(1971). Malone meurt. Paris, Éditions de Minuit. 
London, Pan Books.

(1979). Malone Dies, in The Beckett Trilogy, "Picador,"

KRISTEVA, Julia (1974). La Révolution du langage poétique. Paris, Éditions du Seuil.

SKEAT, W. W. (1921). An Etymological Dictionary of the English Language. Oxford, Clarendon Press. .

\section{Appendix}

Fakir Mohan Senapati, Chha Mana Atha Guntha, chapter 22.

Translation 1 (Passage translated by K.M. Acharya, published in Modern Indian Literature, an Anthology, ed. K.M. George, New Delhi, Sahitya Akademi, 1992, vol. 2):

Gopalpur Ghat is on the bank of the Nirupa. This is on the road to Cuttack. People cross the river at this point. Here at one time stood the village Gopalpur. In the catastrophic floods of the eighth day of Bhodua in the eighth year the village had been washed away. The village has gone but not its name.

Translation 2 (Unpublished translation by Rabi Shankar Mishra and Jatindra Nayak):

The bank of the river Birupa was the site for the weekly market of Gopalpur. This was also the place where people took the ferry to cross the river on their way to Cuttack. Previously the village of Gopalpur stood here. It had been washed away in a flood in the eighth year of the reign of king Mukund Dev. Although the village was no longer in existence, its name nevertheless persisted. 
Translation 3 (Passage translated by Paul St-Pierre, et al., Translation Workshop, Utkal University, Bhubaneswar, Orissa; February 1995):

Gopalpur Ghat, on the river Birupa, where people cross on their way to Cuttack. At one time there was a village named Gopalpur here, but it washed away in the great floods on the eighth day of the month of Bhodua in the eighth year of the reign of the kings of Puri. The village has now disappeared, but its name lives on.

Translation 4 (The Stubble Under the Cloven Hoof, trans. C.V. Narasimha Das, Cuttack, Sahitya Samsad, 1967):

Water-logged Cuttack stands ensconced, like the nest of a tern on a sandy island, amidst the ramifications of running waters and alluvial banks. The slender Birupa, like the spacious Mahanadi which flows by its side, meanders on the north and seems to guard the northern approaches to the city like a redoutable sentinel, next in command to the gigantic Mahanadi. This second aquatic line of defence which Nature has provided Cuttack with, that is, the river Birupa, admits travellers into that city across its breast by inviting them to cross the stream in a ferry-boat at a point known as Gopalpur ghat. This spot is the water-front where the ferry links the two banks of the meandering stream; and the people who desire to go to Cuttack from the villages on the northem bank are ferried here across the river. The village of Gopalpur stood on the bank hereabout before the great floods came and washed it away on a certain inauspicious Ashtami day, that is, the eighth day after the Full Moon, in the month of Bhadrava many years ago. The village is gone like all other ill-starred victims of Nature's violence, lock, stock and barrel. Although no physical trace of it is found today, the village has left its undying name at the ferry so that generations might rake up their fertile imagination and their fancy and spin stories and weave legends around the name. 
Translation 5 ( $A$ Plot of Land, trans. Nuri Misra, Cuttack, Cuttack Students' Store, 1969):

The Gopalpur ghat on the bank of river Birupa was on the way to Cuttack. The travellers had to cross the river at this place.

\begin{abstract}
Translation as Writing Across Languages: Samuel Beckett and Fakir Mohan Senapati - This paper attempts to demonstrate that translation cannot be divorced from writing, that originality and creativity are not characteristic only of the latter, that translation is not mere reproduction. This is developed in relation to Samuel Beckett's translations of his own works and five translations of a passage of a late nineteenth-century Indian novel. In the case of Samuel Beckett, transiation is seen as a way both to begin and to continue the writing process, a way for him to explore one of the principal themes of his work, the relation of writing to language(s). In that of the five translations into English of a passage from the Oriya novel by Fakir Mohan Senapati, Chha Mana Atha Guntha, the differences between them are examined for the purpose of showing the extent to which the practice of translation is always an act of creative writing.
\end{abstract}

\title{
RÉSUMÉ : Translation as Writing Across Languages: Samuel
} Beckett and Fakir Mohan Senapati - En prenant pour exemples les traductions par Samuel Beckett de ses propres textes et cinq traductions d'un passage d'un roman indien de la fin du dix-neuvième siècle, cet article veut démontrer que l'on ne peut séparer d'une manière absolue la traduction de l'écriture, que l'originalité et la créativité ne sont pas les attributs de cette dernière seulement, que la traduction ne se réduit pas à une simple reproduction. Dans le cas de Beckett, la traduction a pour fonction de lui permettre de commencer et de continuer à écrire; c'est un moyen pour lui d'explorer un des grands thèmes de son ceuvre, la relation entre l'écriture et la ou les langues. Dans celui des cinq 
traductions du passage du roman en oriya de Fakir Mohan Senapati, Chha Mana Atha Guntha, les différences entre les versions sont examinées afin de faire voir jusqu'à quel point la traduction est toujours un acte de création.

Paul St-Pierre: Dép. de linguistique et de traduction, Université de Montréal, C.P. 6128, succ. Centre-ville, Montréal, Québec, H3C 3J7, CANADA 